\title{
Postmodernism, Christian Patristics, and Values of Peace in the Modern Cultures
}

\author{
In the Context of Educational Process
}

\author{
Olga Chistyakova \\ Russian State Specialized Academy of Art \\ Moscow, Russia \\ Department of Social Philosophy \\ Faculty of Humanities and Social Sciences \\ Peoples' Friendship University of Russia \\ Miklukho-Maklay str., 10/2, Moscow, Russia, 117198 \\ E-mail: olgachis@yandex.ru
}

\begin{abstract}
The article offers a review of selected postmodern principles relating to the analysis of religious and spiritual spheres of society in terms of their importance for culture and education. The author shows the concept of a new kind of American theology that is close to the politicized and technologized postmodern society. The values of the Christian patristics considered through the view of methodological tools of postmodernism, presented as humanistic values of any modern society. The principles of postmodern philosophy are presented by the author as an essential means of social analysis in the educational process.
\end{abstract}

Keywords-postmodern philosophy; Patristics; modern culture and education; American theology; anthropological values; study of Peace

\section{INTRODUCTION}

Education in modern societies reflects the changed nature of the societies themselves, which are radically different even in comparison with the second half of the 20th century. Engulfed by the postmodern processes, these societies are informational by their nature and are subject to the strong influence of the mass media. Education is also experiencing a great influence by the information coming from the media.

Under aforementioned conditions emerges a problem of obtaining objective knowledge and choosing methodological tools of analysis for incoming information. How does one distinguish objective information from biased information and by what means can we come to the understand the truth? In our opinion, postmodern philosophy can act as one of such educational methods. Some of the postmodern methodological means are very up-to-date and reflect the current problems of the transforming societies in their fast historical development. Postmodernism as the principle and the method of analysis of current events is realized today even in as specific area such as theology. The article offers a review of some of the postmodern principles in their relation to the consideration of spiritual and religious spheres of society in terms of their importance for culture and education.

\section{POSTMODERnism ANd A NeW TyPe OF THEOLOGY - "AMERICAN THEOLOGY"}

We witness today erosion and vanishing of wellestablished social institutions of late modernity that are being substituted by postmodern institutions, that do not exclude theology and strive of a modern human to religious selfidentity. The notion of God is being interpreted anew in described chaos. We attribute described processes to those defining postmodernity and postmodern theories trying to capture the state of the postmodern society. Worth noting that the postmodern condition stems from the western societies of the late $20^{\text {th }}$ century. Speaking of theoreticalreligious postmodern representations, we should mention concepts united under the "American theology" roof. These concepts capture the changes happening in the western civilizations since the last decades of the $20^{\text {th }}$ century and offer a new typology of God mirroring the tendencies existing in American and other western societies. These tendencies include rapid development of the IT and the society's technocratization that follows it, growing media influence on individuals and society, actualization of the political sphere under the dominance of democratic ideas, urbanization and, most importantly, individuals' and society's quest for identity.

The processes of self-identification found in the postmodern American society actualize also as a search for "self" in religion. For example, Frederick Sontag and John K. Roth in their "The American Religious Experience" [1] state that the way out of the inflicted crisis of self-identity shouldn't be completely secular. American social scientists connect the search for identity to the possibility of answering the question "What does it mean to be an American?" This whole process becomes apparent as a way of uncovering the new theology or even the new theoretical form of God, as the authors view the crisis of self-identity as a manifestation of the crisis of the American theology. We may easily acquit them as the American nation since its very beginning was a result of pilgrims' puritan religious and theologically based 
self-consciousness. As a theological concept can't emerge out of nowhere, American religious philosophers and theologists set their goal to analyze retrospectively and on the value basis the correlations between restoration of American theology and possibility of American Renaissance based on self-identity [1; P. 4-5] The aforementioned authors are to interpret the history of the state and to draw its future in religious categories.

Orientation toward religious past and its theoretical synthesis with modern-day sociocultural processes lead us to the new conceptual names of God, witnessing an injection of postmodernism into religion. We should mention that Orthodoxy strongly denies such new names and postmodern concepts, but let us introduce you to some of the postmodern theological ideas found in the works of the American scholars.

Herbert Richardson issues the idea of the system of an "own American theology". His assumptions, however, don't refer just to the American philosophical and theological tradition but are a part of a modern American culture and society of professional management, IT, and etc. According to Richardson, an individual will have to live in a rapidly developing technocratic society that will demand new concepts to fill in the spiritual vacuum. Richardson suggests compensating the "spiritual emptiness" of modern culture by synthetic notions of "socio-technical God" and "cybernetic God" reflecting the relationship between reality and man's thirst for religious values.

Philosopher suggests that "socio-technology", as a new knowledge, by which individuals gain access to the technological control over society, is actually a root of many problems considering religion. He marks off that "theology should develop the concept of God, that should support the first reality of the cybernetic world", world of "systems" and "matrices" [2; P. 23]. Richardson's "Socio-technical God" should help each and every one join the world of faceless machines and the coming of artificial intelligence.

However this theoretical innovation by Herbert Richardson is obscure and uncertain due to the lacking of theoretical and philosophical argumentations. What is the status of "socio-technical God" and what is His apophatism? How can a Human being think and cognize the God growing from cybernetic world? Would this God be an appealing model for the generations of the young Americans living between technological revolution and human strive for spirituality?

Philosopher Harvey Cox touches upon similar problems. He denies the metaphysical constructions the possibility to describe the relations between a human being and a transcendental world. The American religious philosopher suggests using political idioms because politics brings up the social unity and is very important for human life and human thinking. He introduces the new concept of "political God" revealed in secular political and social events. His "God" implements the functions which are similar to functions of "sociotechnical God" by H. Richardson. The main problem of Harvey Cox' ideas lie in the sphere of cognition. He asks how we could narrow the God in secular notions and positive categories. Thus the thinker comes back to the fundamental problem of patristic literature of the period of Early Christianity.

American philosophical religious discourse offers quite original concepts tying politics and religion. Hannah Arendt states in her "On Revolution", that political and religious spheres in the USA are not isolated from each other [3]. Religion should play the first hand when the spiritual revolution strikes. The key principles of this revolution are: restoration of the original spirituality, expansion of social spends, compassion to those in need, turn for the human factors, etc. Arendt underlines the irony that the USA develops as the world's state but if the aforementioned goals are well-received, they will demand turning to religion [3; P. 85]. Deliverance of suffering and spiritual incompleteness could be achieved, according to Arendt, through the political actions setting religious goals as well. That's why there's political religion developing in the States nowadays that signifies the new turning in the American thinking.

Therefore, there is a religious philosophical school in the USA that aims at creating a "free theology", founded upon analysis of the American political history, social processes and a plurality of theological concepts.

The fundamental idea underlying the creation of the new American theology is one of a democratic God, recognizing and accepting the fact that God's manifestation on Earth is being cognized differently by different people and is actually pluralistic. The chief ideal of "free theology" is thus support of the pluralistic thought based on cultural identity and equality. The "free theologians" suppose that theological reflection helps gathering otherwise scattered social groups as a nation, exactly the way the founding fathers wanted to.

Such reflection upon the roots of the USA combined with the modern-day religious concepts allows us to suggest that deep-laid philosophic-religious ideas can be viewed from the problems of the modern-day society. Reasonable theoretical argumentation helps us to use the values of the past in order to analyze and foretell society's development. Exposure of the fundamental civilizational and anthropological structures in their historical perspective allows us to introduce a sole spiritual basis for the peaceful coexistence of the countries and regions, culturally and religiously different a-priori: the West, the East, Russia and ex-USSR countries.

\section{PATRISTICS AS MODERN AXIOLOGICAL SYSTEM AND MORAL BASIS FOR CULTURE AND EDUCATION}

From our point of view, the theoretical ideas of early Christian thinkers correlate the best with the aim of forming of the entirely axiological, cultural, inter-civilizational basis of diversity of modern countries. We mean the ideas and ideals of Eastern (Greek-Byzantine) and Western (Latin) patristic with the Holy Fathers' creations, who worked out the anthropological conception of Christianity simultaneously with forming of Christian dogma between IV and VIII centuries. Orthodox-patristic discourse has the following positive features: it's independent from the state, political, social, economic lines and statements. The main idea of the patristic heritage founds progressive development 
of spiritual culture; substantiate the way of increasing of spiritual creation of people, priority of rationalism, nonexcepting, however, values of man's personality.

Correspondence of patristic ideals with present doesn't mean their blunt coping or imitation. The sacred heritage gives the opportunity to understand, as this original culture is acceptable for contemporary human upbringing, for his creative forces, and for his self-implementation. Moreover, in definite philosophical reflection the Christian anthropological these could occur moral and culture forming primary sources of modern state being.

If we had been carried back to the epoch of early Christianity, we would have seen the new style of "cultural behavior", in which universal moral values had turned to be more important than the ones of a nation or a class, and a humanistic approach had been introduced alongside with "canonization" and "authorization", reorienting ethic notions to spirituality and universal human sense. At the same time Christianity didn't prevent different ethnos from preserving their peculiarities or "cultural handwriting". The cultivating of personal existential values was the feature of early Christian Patristic.

Discussing role of religions in development of education in global world, it's important to reapproach the philosophical ideas of Human being of early Christian thinkers (stressing the Western and Greek-Byzantine Patristic of the IV-VII centuries) by the methods of postmodern philosophy. Christianity can be characterized as sufficiently modern axiological system through the viewpoint of postmodernism. Early Christianity was formed both as the syncretic religious system and as the philosophical one. It was founded on the Antic Greece philosophy, concepts of Platonists, and creations of Holy Fathers. Hence the main ideas of Early Christian thinkers obtain actual and rational positions in the contemporary society, of course depending on their interpretations, presentations, and usage. Religious notions and values are able to take a significance of secular ones in cultural and moral lives of people if connected to the thinking of a human being and contributing positively to the development of modern person and society in whole.

\section{THE MAIN ANTHROPOLOGICAL IDEAS OF PATRISTICS AS SECUlAR AND ACTUAL ONES}

We would like to draw some examples of philosophical and anthropological ideas of Holy Fathers (Patristics), which are supposed to be the most actual, modern and suitable for the contemporary world. They contribute to the formation of educational and cultural space with the principles of Peace, without violence and conflicts.

1. The central idea of Greek-Byzantium culture was the understanding of personality, its essence, and advisability of existence. Human beings are between society and God and therefore link between them is personal and alive church communication in spirit (later it was depicted in notion "sobornost" in the Russian religious philosophy). The human in Christianity is personality in spirit, individual by nature. The most prominent philosophical line of the Eastern patristic is a thesis of a wholeness of man possessing "God's image" and inspired by God's spirit, may serve as a base and an aim of being of the objective world.

Exactly the "Spirit" in Christian religious tradition is presented as able to take a man out of the scopes of objective world. It comes out as the term of possibility of human being transcendence, to reach which personality can only in nature perfection, common for all people in their essence, which Holy Gregory Nisskiy called as "all-unity" of mankind. Approximating through "Spirit" and mind to the Absolute, the man opens himself to Heaven.

2. Substantiation of the Old Testament understanding of human being which God created in His own image and likeness. The interpretations and discussions of this idea inspired to early Christianity the anthropological character. This thesis of Old Testament substantiated a human being like a center of Universe thus a Person was closely approached to God.

Holy Iriney Lionskiy, Tertullian, Kliment Alexandriyskiy, Gregoriy Nisskiy, Aphanasiy the Great, Vasiliy the Great, Gregoriy Theologian wrote on this topic. They saw the intention of person the way to recovering the lost likeness to God, the possibility of infinite spiritual self-perfection and obtaining knowledge and moral notions. This way was described as the way of deification, in other words, it was a method of willful perception by a person his or her best qualities, uniting the aforementioned person with God. Thus, in Holy Fathers' thinking, exactly human being removes the contradictions between terrestrial world and transcendental one. Hence, in Patristic, a human was approximated to God or Absolute.

The early Christian thinkers fixed a contradiction, an “abyss" between God and humans. Human aren't God, but human a-priori possesses the striving for God, the willingness of potential overcoming of this abyss. To solve the noted contradiction patristic introduced the discussion on the meaning and role of following notions - the "God's own image" and "likeness". Modern Russian philosopher and theologian Andrey Kuraev noticed that "God's image" is the possibility of a human's likeness to God. The Image of God is striving desperately to obtain the God's likeness. Consequently, the God's likeness in a human being means the God's features (wisdom, love, mind, beautiful, etc.) which a human possesses. Human life is thus rising up from the Image to Likeness [4; P. 117-118].

According to early Christianity, each human being can become "God by divine grace". It was emphasized that a human desires to acquire the divine qualities by the very personal way and infinite spiritual ascent. By that desire the human unites the terrestrial, sensible world and the transcendental, divine one. Thereby in reflection of Holy Fathers the aforementioned Old Testament Canon signified the overcoming of dualistic nature of human being by the unity with God of personal, individual, free and rational human's nature. Worth noting the words of Holy Afanasiy the Great who wrote: "The way to God isn't far from humans, it isn't out of us, quite the contrary, it is inside us. And the starting of this way can be possibly found out personally. 
What is this way? - The soul of everybody and the mind inside it; because only mind is able to contemplate and cognize the God" [5; P. 165-166].

Consequently, the religious writers elaborated the image of the only creature in the world, who was able to remove dualism of Heaven and Earth and reconcile spiritual and material being. The "cosmic" aim of a human being rose from this task: to lead the Earth imperfect world to harmony and "Divine" consent. Gregory the Theologian remarkably defined a man as the "creature", which stops animosity of spiritual and corporeal: "Human consists of spirit and body. And a spirit is a ray of endless light-Deity; and body you produce from the dark origin. If I am of one common nature, than hostility is stopped... Not hostile, but friendly sources give the whole composition" [6; P. 25]. The nature of a person is directed to spiritual equality with God, and means for establishment of absolute harmony in the world of earthly things.

Maxim the Confessor affirmed that the main predestination of man is the unity of earthly world with Logos, but for it a man must perform God's features at first in himself, so far as a man is a microcosm, absorbing all elements of microcosm and the Universe. These ideas show the Greatness of man's purpose in the world of his being in impracticability of its purpose on reason of misunderstanding of its aim and abuse of liberty. Aren't these ideas actual at the beginning of the third millennium?

From the gnoseological aspect of Eastern patristic anthropology, the idea of self-cognition of soul and personal inner world is the first step of cognition of God. Here we go on to the next problem of Patristic that is supposed to be very important and actual one.

3. The cognition of God is simultaneously self-cognition and self-development of a human being. The Christian authors showed by one's work the possible ways of God's cognition and at the same time the individual self-cognition and self-determination. The most important works on this topic were written by Holy Iustin, Ioann Lestvichnik, Dionisiy Areopagit, Simeon Noviy Bogoslov, Gregoriy Palama, Maksim Ispovednik and some others.

In Christian theology the notion of God is contradictory. God can simultaneously be cognitive in His phenomena and not cognitive in His essence. Absolute/God gives person the opportunity of his cognition by different ways. This opportunity can be given to an individual who is selfconscious, ready to reveal his or her internal existential feelings and qualities, showing rational realization of the world etc. The cognition of God depends on moral and thinking activities of the very human being. In this context human's freedom was put in accordance with mind, rationality and man's activity. A human consciously "leads his nature", has power over his actions and wishes. "When it is necessary, the freedom of decision is connected to mind, because either a human won't be reasonable, or, being reasonable, he will be the master of his actions and independence" [7; P. 109] - John Damaskin affirmed.
Thus, the process of personal self-determination was regarded by religious writers as coinciding with process of God cognition and self-cognition. At the same time opening possibilities of self-cognition in theology had enough secular meaning, as it accented on cultivation of inner traits and characteristics of a human, developed psychological peculiarities of separate personality, taught to "art of management" by human all great number of their energies, thoughts, aspirations. In the Patristic anthropology human's self-cognition is self-feeling and the "way to himself", that is the process of personal self-consciousness and self-creating through the search of moral ideals, through comparison his actions with Absolute moral of God. Personal selfconsciousness and cognition of the Divine grew according to the fact that a human being becomes more perfect, unrestrained.

A category of energy plays a great deal in Christian theory of cognition. Early Christian theologians divided the understanding of God's nature into two moduses depending on the energy - in essence and out of essence. Feeding on energies, a human enters a covenant of the Holy Trinity. Receiving God's energy allowed a human to enter God's grace thus forming a unity with God, just as a God's gift to a human. God's infused energies are the relationship between God and created reality. Human's notion is thus to cognize, receive and follow them. Cognition of God was treated as a cognition of energies, personal feeling of God.

The notion "energies of God" have an important place in the Christian theory of cognition. Using the term "energy", the early Christian theologians categorized the understanding of God' nature on two modi - in essence and out essence. Apprehending the energies of God, a human being simultaneously receives the Lord's Sacraments and become closely to the Holy Trinity. The perception of the energies of God was claimed as the unification of man with God on the base of Divine grace, as the honored gift of God to man. The God' energies are the relationships between Creator and His creations. The main destiny of human being consists in the cognition and implementation upon a virtuous way of life. Thus, the cognition of God was interpreted by the Holy Fathers as comprehending of Divine' energies, as personal deep sensation of God.

Holy Fathers created a diversity of interesting conceptions for illuminating the human's ways of God's cognition, for receiving His reveals through the Divine energies. Kataphatic and apophatic theology of the IV-VIII centuries tried to "describe" the God by the special definite categories and show how it was possible to understand and cognate the Creator of our world on the level of theologian notions. The apophatic (negative) theology occupied the dominating role in the Patristic thinking and guessed that God's essence may be only the un-cognitive one. Human is able to cognize the negative characteristic of the God; he/she can get to know the phenomenon and features which the God doesn't possess. The positive (kataphatic) characteristic immanently belongs to the God, but a human's mind isn't able to get to comprehend them through the life experience. 
The conceptions of liturgical, symbolical and imaginable, artistic cognition of God were founded as the original teachings of ascetical monk's way of reaching unification with Holy Trinity (for example, a conception of obtaining the God via thirty moral steps of man' deification, created by Ioann Lestvichnic - IV century). Later, in XI and XIV centuries the unique conceptions of God cognition through the peculiar, immaterial, "Divine light" (Simeon Noviy Theologian) and "Phavorskiy light" shaped by the practice of Hesychasm (Grigoriy Palama). However, all these conceptions were connected to the anthropological ideas of Christianity and had a philosophical character as they had been substantiated spiritual and moral beings of man, the methods of his self-development and self-cognition. A clearly formulated ways of ascension to God were the fundamental bases of religious philosophy of Byzantium.

It is significant that Patristic points out one of the many methods of individual's self-determination, stresses a man's purpose as a creative search for the meaning of existence. From a line for the man activity, belief in his spiritual opportunities, the most important religious-philosophical statement, which hasn't lost its rationality today, flew out: the human being should create perfect life - personal and public - by himself naturally and really. The man should safe himself from submission of society, state, nature, civilization, but at the same time he shouldn't cross the thin brink between liberty and anarchy. Otherwise the fine Christian postulate about liberty of self-determination of person becomes as a means of justification of violence, allpermission and social chaos.

\section{PATRISTICS IDEAS IN CONTEMPORARY EDUCATION THROUGH THE POSTMODERN PHILOSOPHY}

How in particular can we make use of these perfect anthropological ideas in our everyday educational experience taking into account their historical remoteness? Approximately the same way as the American theologians and philosophers try to rethink and apply their historical heritage. Here the postmodern philosophy again comes to the rescue.

In my opinion, the best way to study, interpret and to use the Patristic texts for removal the all forms of violence, religious and ethnical discriminations in modern societies is the postmodern methodology of the French philosophers (Jean Baudrillard, Jacques Derrida, Jean-François Lyotard, etc.). The basic principle of the postmodern philosophy is the thesis that the postmodern society has been radically transformed into something completely new and thus demands the new interpretations and methods of analysis. Postmodernism isn't interested in historical facts, what really matters, is the present, which could be derived from the past. The facts from the past are being viewed from here and now. Any situation could be taken from anywhere, and it doesn't matter from where exactly. According to my understanding, this methodology could be used to interpret the texts of the early Christianity. Ideas and doctrines of the Holy Fathers are thus being transformed into something actual for the modern-day people. The principles of postmodernism shape the anthropological ideas of Patristic and make it out of time phenomenon. That is why the search for the roots of postmodernism can lead us to Homer, Plato, Vasily the Great or Gregoriy Nisskiy.

The aforementioned Holy Fathers' ideas viewed from the postmodern point of view allow us to draw the following conclusion - a human being is the main symbol, synthesizing the whole symbolics of the Universe in his or her inner life. From the Patristics' point of view, a human's goal and prescription is understanding and explanation of an objective world as God's symbols and creations. A person, exploring the secrets of life, bears responsibility for the world around thus binding together God and a human being, religious and mundane, spiritual and materialistic. Such reasoning, stemming from the past and being developed by the modernday philosophy, has humanistic meaning and could lead to pacifism in the modern societies.

Postmodern philosophy sets an extremely important problem acute to any religion as well as to the modern-day American and Russian philosophies. This is a problem of man's searching of self-identification in the controversial and complex world. Postmodernism points out that for process self-identification it is necessary to have an Other (a human being, group of people, others books, ideas, teachings, thoughts, etc.). Nevertheless, in the postmodern era the Other acquired an exotic nature, as J. Baudrillard would have put it [8]. The place of the Other was substituted and occupied by Screen, Computer, streams of mass media information. French philosopher wrote that a screen of computer was the Other in our epoch of postmodernity and it had become "a pure form of communications" [8; P. 23]. Under these circumstances the process of self-identification is limited because the traditional social relations were changed by the communications among humans and machines. The real social contacts and connections were replaced by simulation and artificial ones. Because of it, J. Baudrillard stressed the attention on the problem of possibility of self-identification in postmodern societies - he claimed that it was a problem of searching of connotations, differences One from Other, i.e. from models, machines, from artificial codes which dominated human's life [8]. Thus, J. Baudrillard is pessimistic: he assumed that the contemporary society directed at destruction of the identifying characteristics of Other and mass media supported this notion. As a result human being enters into the inner conflict with self and society starts to suffer of "allergy on itself" [8; P. 53].

The process of self-identification gets limited in the era of global postmodern transformations deinstitutionalizing social institutions and isolating individuals from one another (J.-F. Lyotard) [9; P. 17]. The communication among people and society members would be indefinite, superficial without self-identity, that's why the search for identity worries every single society. British philosopher Zigmunt Bauman connects search for self-identity to the ongoing processes of decentralization and deregulation of social life. Human's self-identity should replace the loss of control over one's life and complete the sense of life in an endless and bottomless stream of social time [10; PP. 142; 256]. 
Bauman derives the solution to the identity problems from completing the identification processes that simultaneously serve as foundation for an individual's selfidentity and completion of an objective process of desocialization rooted in modernity. A human's primary goal is thus to steadily define self instead of existing in diffused social conditions of modernity. Sociocultural processes, changing society's values, also influence members of that society. That means that a new image of society literally demands individual in it more than it was in society of modernity. Primary social principle of postmodernity is to perceive every member of society as an individual [11: P. 39].

\section{CONCLUSION}

Having observed some ideas of postmodern thinkers and critical theoreticians, we can see that the anthropological problems penetrate all historical periods. An axiological basis of human being is beginning the most significant for comprehension of existence of man and for understanding of his relations with other people, God, state, other viewpoints. In this context philosophical-anthropological values acquired the characteristics of intercivilizational ones, are able to unit all people from different epochs and cultures. Such kinds of values always were and would be actual, important, and generally valid for society independently on religious identification, territorial location, temporal space, forms of state management, etc. Postmodern methodology allows considering these values as up-to-date and actual realities of life.

Comprehending the past from the postmodern point of view leads to the synergetic wholeness of religious and postmodern philosophies, modern types of theological interpretations of these sources and theoretical principles of postmodern philosophy. Such position allow us to pursue our primary thesis and discover the Greek-Byzantine and Western Patristic, analyzing them through the Postmodern principles, as one of the most important theoreticalaxiological means of education.

Early Christian ideas on mankind and humanity, spiritual ideals of the Holy Fathers are the basic ideas that could lead to moral, merciful and beneficial global peace. Cultural, religious and spiritual values bind states and peoples together in the age of globalization.

\section{REFERENCES}

[1] Frederic Sontag and John Roth. The American religious experience. The roots, trends, and future of American theology. New York: 1996.

[2] Herbert Richardson. Toward an American Theology. New York: Harper and Row, 1997.

[3] Hannah Arendt. On revolution. New York: Viking Press, 1985.

[4] Andrey Kuraev. Pupils' Theology. Moscow: Academia, 1997.

[5] Aphanasius the Great. Creations. In 2 vol. V. 1. Moscow: Bogosloviye, 1994.

[6] Gregory the Theologian. 1987. Word About World: Creations. In 2 vol. Vol. 1. Saint-Petersburg: Podvoriye.

[7] John Damaskin. The accurate statement of Christian belief. Rostovon Don: Orthodox Church publication, 1992.
[8] Jean Baudrillard. 2000. The Lucidity of Evil. Moscow: Dobrosvet.

[9] Jean-François Lyotard. The Postmodern Condition. Moscow, St. Petersburg: Aleteya, 1998).

[10] Zygmunt Bauman. The Individualized Society. Moscow: Logos, 2005.

[11] Zygmunt Bauman. Liquid Modernity. Moscow: Piter, 2008. 
